\title{
ANALISIS PENGARUH INFRASTRUKTUR PUBLIK TERHADAP PRODUK DOMESTIK BRUTO PERKAPITA DI INDONESIA
}

\author{
Eko Fajar Cahyono \\ David Kaluge \\ Fakultas Ekonomi Universitas Brawijaya Malang \\ Jln. MT. Haryono No.165 Malang (0341)551396 \\ E-mail : fajars2ie@gmail.com
}

\begin{abstract}
This study aims to measure how far the influence of public infrastructure such as roads, electricity, and telephone to Gross Domestic Product in Indonesia. This research is based on the theory of classical and neoclassical economic growth which assumes that the infrastructure is physical capital that relate either directly or indirectly to economic growth. This research used error correction model analysis and time series data. Based on estimates found that public infrastructure have a significant and positive impact on Gross Domestic Product.
\end{abstract}

Key Words: Product Domestic Bruto, Infrastruktur Publik, Teori Pertumbuhan Ekonomi, Jalan, Listrik, Telepon

Sebagai sebuah negara berkembang, Indonesia terus berupaya untuk mensejahterakan rakyatnya. Bidang ekonomi adalah hal penting yang terus menerus diperhatikan oleh pemerintah. Secara umum tujuan negara dalam ekonomi makro adalah untuk mencapai stabilitas ekonomi, pertumbuhan ekonomi yang tinggi, Produk Domestik Bruto serta penganguran yang sedikit. Pemerintah dalam rangka mencapai tujuan tersebut memerlukan berbagai faktor pendukung yaitu salah satunya yang penting adalah keberadaan infrastruktur. Dengan adanya infrastruktur yang baik diharapkan merangsang dunia usaha akan menanamkan modalnya dalam investasi langsung sehingga dapat mempertinggi pertumbuhan. Infrastruktur yang baik juga akan memberikan akses yang lebih luas untuk menikmati sumber daya.

Investasi Indonesia untuk infrastruktur sangat tidak memadai. Hal ini dapat dilihat dari semakin menurunnya investasi. Contohnya investasi infrastruktur dari 5-6 persen dari PDB sebelum tahun 1997 menjadi kurang dari 1-2 persen dari 
PDB pada 2000 dan tahun 2007 berada dalam kondisi stabil pada tingkat 3,4 persen dari PDB (Bank Dunia,2007:80).

Dalam hal indikator infrastruktur, Indonesia mengalami penurunan dan posisi Indonesia tertinggal dari negara tetangga. Beban listrik yang besar terpusat di Pulau Jawa dan Bali, sementara di pulau-pulau besar lainnya mengalami kekurangan listrik yang sangat besar. Jalan raya perkotaan sudah terlalu padat dan jalan bebas hambatan yang baru yang diharapkan akan membantu mendorong pertumbuhan ekonomi masih dalam tahap perencanaan.

Rasio penduduk yang memiliki akses terhadap air pipa sebenarnya sudah mengalami penurunan akibat penutupan sejumlah fasilitas dan karena pertumbuhan penduduk. Bagaimanapun, pada masa lalu Indonesia pernah mengungguli Thailand, Taiwan, China, dan Sri Lanka dalam Global Competitiveness Report's 1996 tentang Indeks Mutu Infrastruktur secara keseluruhan. Pada 2002, negara-negara ini telah mampu melampaui Indonesia (Bank Dunia,2007:80).

Sektor air bersih dan listrik yang sangat vital mengalami krisis. Kurangnya kapasitas dan daya listrik serta memburuknya layanan air pipa adalah akibat dari tingkat investasi yang rendah selama satu dekade. Penyediaan sambungan kepada konsumen di wilayah Indonesia bagian timur yang memerlukan biaya lebih tinggi terkendala oleh tarif listrik yang seragam bersifat regresif dan tidak memberikan insentif (Bank Dunia,2007:81).

Berdasarkan uraian diatas maka masalah yang ingin diteliti dalam penelitian ini adalah bagaimana pengaruh infratruktur publik yang terdiri dari jalan, listrik, dan telepon secara bersama-sama dan secara parsial terhadap Produk Domestik Bruto di Indonesia.

\section{INFRASTRUKTUR PUBLIK}

American Society of Civil Engineers (ASCE) menganggap definisi yang lebih komprehensif infrastruktur ada pada laporan tahunan "Daftar Laporan Infastruktur Amerika ". Daftar ini memuat data infrastruktur untuk penerbangan, jembatan, bendungan, air minum, energi, tempat limbah berbahaya, jalur air bernavigasi, taman umum dan rekreasi, kereta api, jalan, sekolah, keamanan, limbah padat, jalur transit dan jalur air limbah. Sekali lagi, bagaimanapun, daftar 
laporan tidak menjelaskan mengapa sarana sarana itu dikelompokan dalam kategori infrastruktur (dalam Dixon dan Baldwin, 2008:17).

Karateristik infrastruktur adalah: (1) Aset memiliki bentuk fisik dengan masa pakai yang panjang. Penciptaan aset memerlukan cukup periode persiapan pembangunannya; (2) Aset memiliki sedikit pengganti dalam jangka pendek; (3) Struktur aset mampu memperlancar aliran barang dan jasa dan tanpa asset akan terjadi gangguan dalam aliran persediaan barang dan jasa; (4) Aset penting terutama karena asset berfungsi sebagai barang komplementer atau pelengkap terhadap barang dan jasa dalam faktor produksi; dan (5) Memiliki ekternalitas positif yaitu daya manfaatnya dapat dinikmati pihak diluar pembuat infratruktur tersebut (Baldwin dan Dixon,2008:20).

Bank Dunia (dalam Wahyuni, 2009:20-21) mendefinisikan infrastruktur ekonomi, merupakan aset fisik yang diperlukan untuk menunjang aktivitas ekonomi baik dalam produksi maupun konsumsi final, meliputi public utilities (tenaga, telekomunikasi, air minum, sanitasi dan gas), public work (jalan, bendungan, kanal, saluran irigasi dan drainase) serta sektor transportasi (jalan, rel kereta api, angkutan pelabuhan, lapangan terbang dan sebagainya).

\section{PERTUMBUHAN EKONOMI}

Pertumbuhan ekonomi suatu negara dapat tercermin dalam produktivitas suatu negara. Produktiktitas dalam arti sempit adalah “....jumlah barang dan jasa yang dihasilkan seorang pekerja per jam kerja...”. Sedangkan untuk definisi produktivitas negara dapat dikatakan adalah jumlah barang dan jasa yang dihasilkan oleh seluruh penduduk negara itu secara agrregat. Menurut Mankiw (1997:173) produktivitas dipengaruhi oleh faktor-faktor sebagai berikut yaitu modal fisik, modal manusia, sumber daya alam, dan pengetahuan teknologis.

Salah satu bagian dari barang modal fisik adalah infrastruktur (Case dan Fair, 2004:330). Sebuah negara jika memiliki lebih banyak peralatan dan infrastruktur yang jumlahnya lebih banyak maka negara tersebut kemampuan berproduksinya akan lebih meningkat dan lebih banyak.

Teori pertumbuhan Neo Klasik, permintaan masyarakat tidak menentukan laju pertumbuhan sebaliknya tergantung dalam pertumbuhan ekonomi tergantung kepada pertambahan penawaran faktor-faktor produksi dan tingkat kemajuan 
teknologi. Pandangan ini didasarkan pada asumsi perekonomian akan tetap mengalami tingkat kesempatan kerja penuh dan kapasitas barang-barang modal akan tetap sepenuhnya digunakan dari masa ke masa. Pertambahan faktor- faktor produksi dan tingkat kemajuan teknologi akan menjadi penentu sampai dimana perekonomian berkembang (Sukirno,2007:263-264).

Dalam teori Neo Klasik rasio modal produksi dengan mudah mengalami perubahan. Kombinasi jumlah antara modal yang diperlukan dan tenaga kerja yang diperlukan dapat berubah sesuai dengan kuantitas produksi yang diinginkan. Apabila modal yang tersedia sedikit, maka tenaga kerja yang digunakan banyak sebaliknya apabila modal yang digunakan banyak, maka tenaga kerja yang digunakan sedikit. Dengan kata lain terdapat fleksibilitas yang menjamin kebebasan perekonomian dalam menentukan alokasi modal dan tenaga kerja (Rahardja dan Manurung, 2005:148-150)

Teori pertumbuhan neoklasik mempunyai suatu persamaan yang umum untuk menjelaskan teorinya yaitu suatu persamaan yang dikembangkan oleh Charles Cobb dan Paul Douglas, yang secara lazim disebut fungsi produksi Cobb douglas. Fungsi tersebut dapat dituliskan secara berikut :

$$
\mathrm{Y}_{\mathrm{t}}=\mathrm{T}_{\mathrm{t}} \mathrm{K}^{\alpha}{ }_{\mathrm{t}} \mathrm{L}^{\beta}{ }_{\mathrm{t}}
$$

dimana:

$\mathrm{Y}_{\mathrm{t}}=$ tingkat produksi tahun $\mathrm{t}$

$\mathrm{T}_{\mathrm{t}}=$ tingkat teknologi tahun $\mathrm{t}$

$\mathrm{K}_{\mathrm{t}}=$ jumlah modal kapital pada tahun $\mathrm{t}$

$\mathrm{L}_{\mathrm{t}}=$ jumlah tenaga kerja pada tahun $\mathrm{t}$

$\alpha=$ pertambahan produksi yang diciptakan oleh pertambahan satu modal

$\beta=$ pertambahan produksi yang diciptakan oleh pertambahan satu unit tenaga kerja.

Persaman diatas dapat diubah menjadi persamaan sebagai berikut :

dimana:

$$
\mathrm{r}_{\mathrm{y}}=\mathrm{r}_{\mathrm{r}}+\alpha_{\mathrm{rk}}+\beta_{1}^{\mathrm{r}}
$$

$\mathrm{r}_{\mathrm{y}}=$ tingkat pertambahan pendapatan nasional

$\mathrm{r}_{\mathrm{r}}=$ tingkat pertambahan teknologi

$\mathrm{rk}=$ tingkat pertambahan stok modal

${ }_{1}^{\mathrm{r}}=$ tingkat pertambahan tenaga kerja

Dari persamaan diatas kita dapat menarik kesimpulan bahwa merujuk teori pertumbuhan klasik, laju pertumbuhan ekonomi negara tergantung kepada tingkat perkembangan teknologi, peranan modal dalam menciptakan pendapatan nasional 
(produksi marginal modal) dikalikan dengan tingkat perkembangan stok modal dan peranan tenaga kerja dalam menciptakan pendapatan nasional (produktivitas tenaga kerja) dikalikan dengan tingkat pertambahan tenaga kerja (Arsyad, 2004:60).

Teori pertumbuhan Harrod-Domar adalah teori pertumbuhan yang berpijak pada asumsi Keynes. Teori ini menyatakan bahwa penanaman modal mempunyai dua fungsi dalam perekonomian yaitu (i) untuk menambah kapasitas barangbarang modal dan (ii) untuk mempertinggi keseluruhan pengeluaran masyarakat. Fungsinya yang terpenting adalah untuk menambah keseluruhan pembelanjaan. Teori Harrod-Domar menganggap bahwa rasio modal adalah tetap, maka keadaan tersebut dapat diartikan bahwa hanya terdapat satu gabungan tertentu modal dan tenaga kerja yang digunakan untuk menghasilkan sejumlah produksi tertentu. Perubahan dalam hal modal, tenaga kerja akan tergantung dari perubahan sejumlah produksi (Sukirno, 2007:264).

Teori pertumbuhan baru menjadi acuan karena relevansinya membahas pertumbuhan. Menurut Raharja dan Manurung (2004:150-152). Persaman Teori endogen digambarkan dengan $\mathrm{Y}=\mathrm{AK}$. Dalam persaman ini, A menggambarkan faktor yang mempengaruhi tehnologi, dan $\mathrm{K}$ adalah modal fisik dan modal manusia (phisycal and human capital). Dalam persamaan ini hal yang harus diperhatikan adalah tiada hasil yang menurun (diminishing return) atas capital dalam formula capital dalam formula tersebut. Hal ini menimbulkan akibat berupa kemungkinan kesimpulanya bahwa investasi dalam modal manusia dan fisik dapat menghasilkan penghematan eksternal dan peningkatan produktivitas yang melebihi penghasilan yang cukup untuk menutup diminishing returns.

Lebih lanjut tentang kesimpulan itu maka investasi yang menghasilkan penghematan eksternal menyebabkan dihilangkanya a dari persamaan Solow, sehingga persamaan pertumbuhan neoklasik $Y=A e^{m t} K^{a} L^{1-a}$ menjadi $Y=A e^{m t} 1 K$ dalam persamaan pertumbuhan ekonomi. Menurut Kuncoro (2006:73) persamaan ini, menunjukan bahwa bagi negara yang miskin modal manusia dan modal fisik yang sedikit sulit untuk menyamai tingkat pendapatan per kapita negara yang kaya kapital, walaupun memiliki tingkat tabungan nasional yang sama besar. 
Todaro dan Smith (2006:174) menyatakan bahwa pertumbuhan ekonomi suatu negara salah satunya bergantung pada investasi komplementer negara dalam sumber daya manusia (pendidikan), infrastruktur atau riset dan pengembangan. Kesimpulan ini diambil Todaro dan Smith berdasarkan model teori pertumbuhan endogen. Model endogen yang dimaksud Todaro dan Smith menggunakan formulasi $\mathrm{Y}=\mathrm{AK}$. Penjelasannya yaitu bahwa produksi dipengaruhi oleh $\mathrm{K}$ yang mewakili modal fisik dan modal manusia serta A yang mencerminkan tehnologi.

\section{Hubungan Infrastruktur dan Pertumbuhan ekonomi}

Menurut Garmendia dkk (2004:04), hubungan antara jasa infrastruktur, pertumbuhan ekonomi dan hasil-hasil sosial seperti bekerjanya Millennium Development Goals melalui saluran-saluran yang ganda seperti yang dilukiskan di dalam gambar 2.1. Kontribusi dari jasa seperti air, sanitasi , transportasi dan energi secara langsung rumah tangga manfaat dan dapat secara dramatis memperbaiki kesejahteraan mereka.

Banyak dari manfaat infrastruktur kepada perusahaan di Prancis, sebagai contoh, bahwa diagram input output mengungkapkan perusahaan perusahaan mengkonsumsi dua pertiga dari semua jasa prasarana (Prud'homme dalam Garmendia, et al., 2004:04). Jadi, dengan demikian saluran perusahaan akan menurunkan biaya-biaya dan, yang paling penting, peluang pasar diperluas (terutama melalui telekomunikasi-telekomunikasi dan pengangkutan). Laba yang hasilnya di dalam daya saing dan produksi adalah apa yang dihasilkan di dalam pertumbuhan ekonomi dan pada akhirnya kesejahteraan.

Gambar 1. menunjukan adanya keterkaitan antara persediaan infrastruktur dengan pertumbuhan ekonomi. Infrastruktur secara tidak langsung akan mempengaruhi pertumbuhan ekonomi melalui jalur rumah tangga (melalui peningkatan kesejahteraan) dan perusahaan (melalui penurunan biaya dan perluasan pasar) yang nantinya akan berpengaruh secara bersama-sama terhadap pertumbuhan ekonomi.

Keterkaitan antara infrastruktrur dan pertumbuhan ekonomi tidak terlepas dari fungsi dari infrastruktur sebgai enabler kegiatan ekonomi. Infrastruktur mempunyai manfaat menggerakan berbagai sektor perkenonomian karena 
dianggap sebagai social overhead capital (Hirchman dalam Yanuar dalam Permana, 2009:11).

Berdasarkan pengkajian dari uraian pada latar belakang masalah, perumusan masalah yang didukung dengan kajian teoritis yang dilengkapi juga dengan kerangka konseptual hubungan fungsi variabel independen dengan variabel dependen, sehingga hipotesis ini dapat dikemukakan sebagai berikut: (1) Bahwa jalan, listrik, air dan telepon berpengaruh signifikan secara bersama terhadap Kinerja Produk Domestik Bruto Indonesia; (2) Bahwa jalan berpengaruh positip terhadap kinerja Produk Domestik Bruto Indonesia; (3) Bahwa listrik berpengaruh positip terhadap kinerja Produk Domestik Bruto Indonesia; dan (4) Bahwa telepon berpengaruh positip terhadap kinerja Produk Domestik Bruto Perkapita Indonesia

Gambar 1: Diagram bagaimana infastruktur mempengaruhi pertumbuhan ekonomi

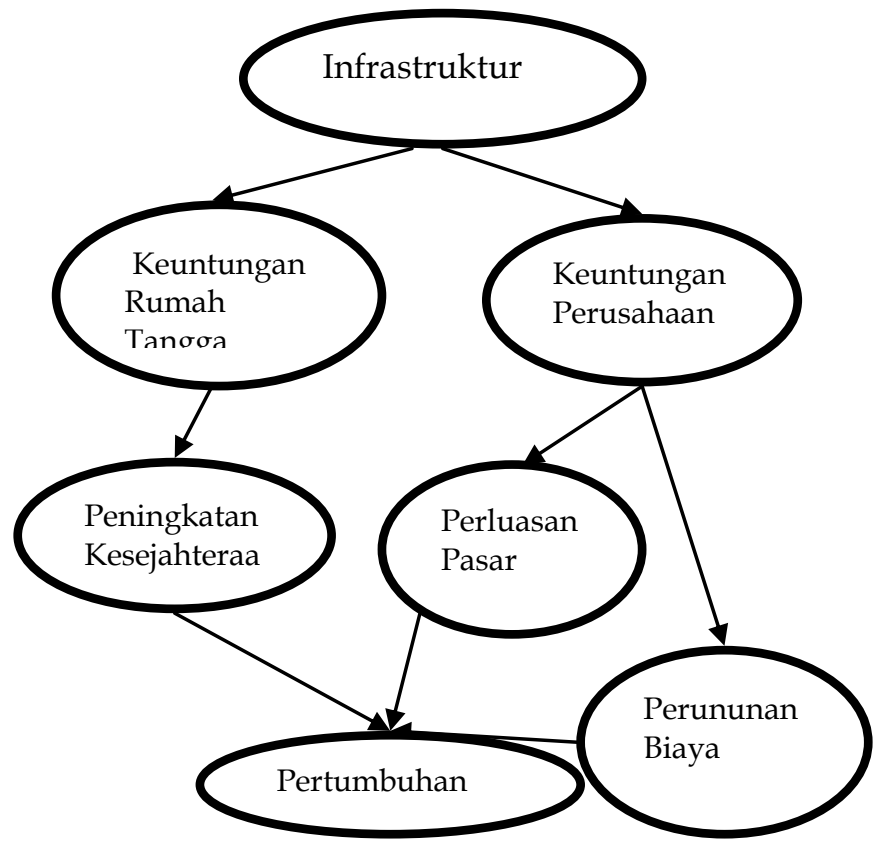

Sumber: Prud'homme dalam Garmendia, et al. (2004:04).

Gambar 2 : Kerangka Pikir Penelitian 


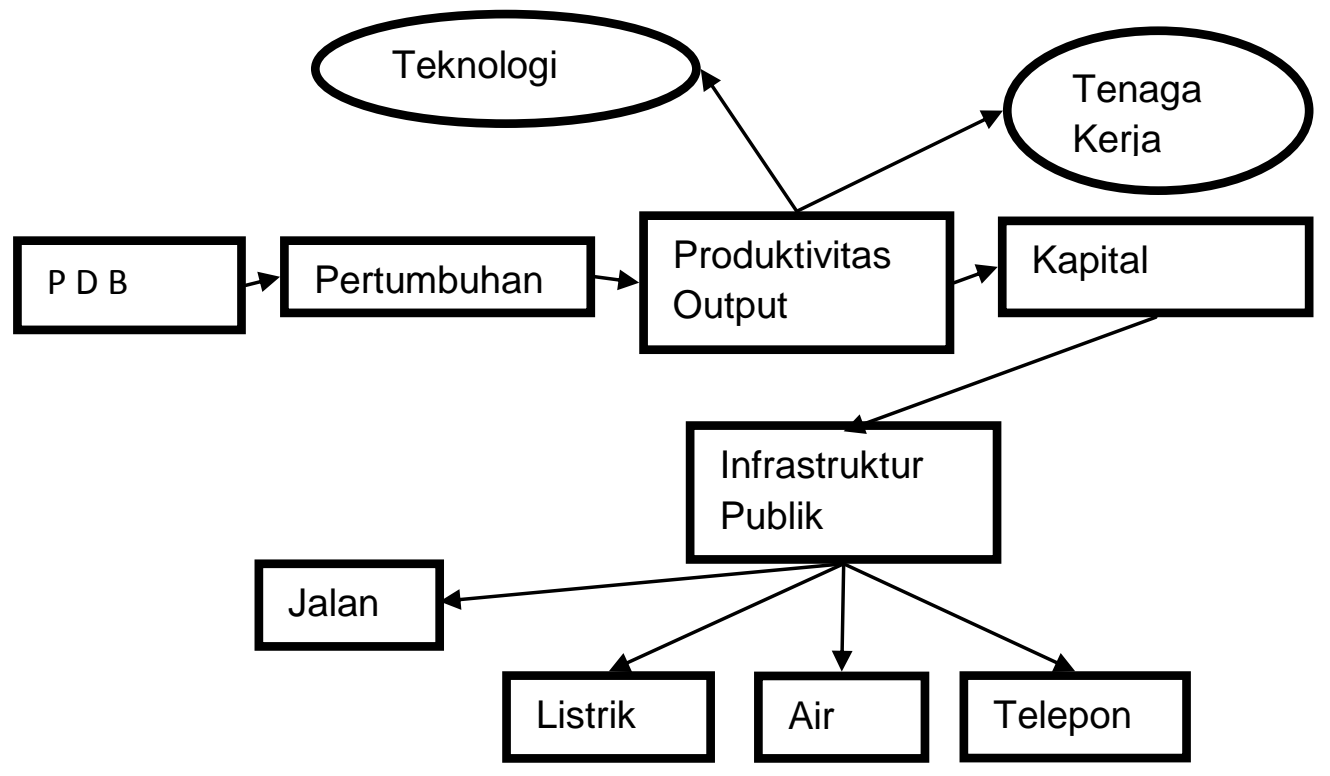

\section{METODE}

\section{Pendekatan Penelitian}

Penelitian ini merupakan penelitian penjelas (explanatory research) karena menjelaskan hubungan kausal antara variabel tertentu melalui pengujian hipotesis. Pendekatan yang digunakan dalam penelitian ini adalah dengan metode kuantitatif. Lingkup penelitian ini meliputi wilayah Indonesia. Waktu penelitian adalah mulai dari tahun 1979 sampai tahun 2007.(data termasuk Timor Leste sampai tahun 1999).

\section{Definisi Operasional Variabel}

Untuk memperjelas tentang variabel yang digunakan maka dipandang perlu memberi keterangan sebagai berikut. Bahwa variabel bebas diwakili oleh Produk Domestik Bruto perkaipta di Indonesia berdasrkan harga konstan tahun 2000, sedangkan penjabaran variabel terikat adalah sebagai berikut: (a) Variabel panjang jalan per luas wilayah (road density) (X1) adalah perbandingan atau rasio antara panjang jalan total (baik yang diaspal dan tidak diaspal) dengan luas daratan di seluruh Indonesia Kepadatan ini diukur menggunakan satuan kilometer per kilometer persegi. Data ini diperoleh dari membagi total jalan tiap tahun mulai tahun 1979 sampai 2007 dengan luas wilayah daratan Indonesia; (b) Variabel konsumsi listrik per kapita (X2) adalah perbandingan total keberadaan lisrik 
dengan jumlah penduduk. Total keberadaan listrik dihitung berdasarkan produksi tenaga listrik dari pembangkit tenaga listrik baik yang berasal proses trasmisi ataupun dari tenaga panas, tenaga lsitrik yang hilang diserap pada saat didistribusikan dan tenaga listrik yang hilang diserap ketika ditransformasi ke bentuk lain ataupun bentuk tenag panas. Variabel ini mengunakan Jumlah tenaga listrik total di Indonesia dibagi jumlah penduduk sehingga ditemukan konsumsi listrik per kapita. Variabel konsumsi listrik per kapita menggunakan kwh percapita / (kilowatthours percapita). Variabel ini dihitung pertahun mulai tahun 1979 sampai 2007; dan (c) Variabel jumlah pemakai telepon dan pemakai telepon seluler per 100 orang (X4) adalah perbandingan atau rasio antara jumlah pemakai telepon dan telepon seluler dengan tiap-tiap 100 penduduk di Indonesia. Sambungan Telepon yaitu suatu jalur yang menghubungkan antara alat transmisi pada telepon pelanggan kepada jaringan telepon publik atau jaringan bersama melalui pusat alat transmisi dalam daerah tertentu termasuk meliputi jasa jaringan digital dan pengguna wireless. Telepon seluler yaitu telepon yang tidak tersambung dengan kabel dan fleksibel untuk dibawa serta menangkap transisinya melalui sinyal di udara. Satuan variabel ini menggunakan satuan jiwa

\section{Metode Analisis}

Metode yang digunakan dalam penelitian ini adalah metode kuantitatif dengan menggunakan alat ekonometrika melalui pengestimasian Engle-Granger Cointegration dan Error Correction Model (ECM) untuk mengetahui faktorfaktor infratsruktur yang mempengaruhi PDB perkapita sebagai permasalahan yang mendegradasi daya saing susu domestik pada jangka panjang maupun pendek yang diestimasi dengan persamaan searah import demand.

\section{Engle-Granger Cointegration}

Kointegrasi adalah suatu hubungan jangka panjang (equilibrium) antara variabel-variabel yang tidak stasioner dan residual dari kombinasi linier tersebut harus stasioner, sehingga dapat mengetahui kemungkinan terjadinya kestabilan jangka panjang antara variabel-variabel yang digunakan. Engle-Granger Cointegration sebetulnya menggunakan metode Augmented Dickey-Fuller (ADF) yang terdiri dari dua tahap. Tahap pertama dilakukan dengan meregresikan persamaan variabel dependen dengan variabel independen ProdukDomestik Bruto 
diregresikan dengan varibael jalan, listrik dan telepon kemudian didapatkan residual (u) dari persamaan tersebut. Tahapan kedua dilakukan dengan menggunakan Augmented Dickey Fuller Test terhadap u. Jika signifikan, maka variabel u adalah stasioner. Artinya meskipun variabel-variabel yang digunakan tidak stasioner, namun dalam jangka panjang variabel-variabel tersebut cenderung menuju pada keseimbangan. Oleh karena itu, kombinasi linier dari variabelvariabel ini disebut regresi kointegrasi dan parameter-parameter yang dihasilkan dari kombinasi tersebut dapat disebut sebagai cointegrated parameters atau koefisien-koefisien jangka panjang (Thomas, 1997).

Tahap kedua adalah mengestimasi regresi, akibatnya koefisien yang diperoleh melalui estimasi regresi menggunakan residual dari regresi lainnya. Hal ini mengakibatkan error yang dihasilkan pada tahap pertama dilanjutkan pada tahap kedua.

Model yang digunakan dalam penelitian ini adalah:

GDP Percapita $=\beta_{0}+\beta_{1}$ Jalan $_{t}+\beta_{2}$ Listrik $_{t}+\beta_{3}$ Telepon $_{t}+\mu_{t}$

GDP Percapita $=$ GDP per kapita harga konstan tahun 2000 pada periode $\mathrm{t}$

Jalan $_{\mathrm{t}}=$ road density pada periode $\mathrm{t}$

Listrik $_{\mathrm{t}}=$ konsumsi listrik per kapita pada periode $\mathrm{t}$

Telepon $_{\mathrm{t}}=$ sambunagn telepon per 100 orang pada peiode $\mathrm{t}$

$\mu_{\mathrm{t}} \quad=$ distribusi error periode $\mathrm{t}$

\section{Error Correction Model}

Hasil estimasi pada pengujian akar-akar unit dan kointegrasi dapat digunakan untuk mengestimasi model dengan menggunakan Error Correction Model (ECM), seperti yang tertera dalam Persamaan berikut ini :

DGDP Percapita $_{\mathrm{t}}=\beta_{0}+\beta 1$ DJalan $_{\mathrm{t}}+\beta 2$ DListrik $_{\mathrm{t}}+\beta 3$ DTelepon $_{\mathrm{t}}+\mathrm{D} \gamma \mu_{\mathrm{t}-1}+e_{t}$

Dimana:

$\mathrm{D}=$ pembedaan pertama (first difference)

GDP Percapita $=$ GDP per kapita harga konstan tahun 2000 pada periode $\mathrm{t}$

$\mathrm{Jalan}_{\mathrm{t}}=$ road density pada periode $\mathrm{t}$

Listrik $_{\mathrm{t}}=$ konsumsi listrik per kapita pada periode $\mathrm{t}$

Telepon $_{\mathrm{t}}=$ sambungan telepon per 100 orang pada periode $\mathrm{t}$

$\gamma=$ eror correction term

$\mu_{\mathrm{t}}=\beta_{0}-\beta_{1}$ Jalan $_{\mathrm{t}}-\beta_{2}$ Listrik $_{\mathrm{t}}-\beta_{3}$ Telepon $_{\mathrm{t}}$

$e_{t}=$ Error distribunce periode $\mathrm{t}$ 


\section{HASIL}

\section{Uji Stasioneritas}

Data deret waktu dikatakan stasioner jika menunjukan pola yang konstan dari waktu ke waktu. Adapun uji akar unit yang digunakan dalam penelitian ini adalah uji Augmented Dickey Fuller (ADF). Apabila nilai t-statistik ADF lebih kecil daripada nilai kritis MacKinnon, maka variabel tersebut tidak memiliki akar unit sehingga dikatakan stasioner pada taraf nyata tertentu. Hasil uji ADF untuk data time series setiap variabel pada tingkat level dapat dilihat pada Tabel 1.

Tabel 1. Hasil Augmented Dickey Fuller pada Level

\begin{tabular}{|l|l|l|l|l|l|}
\hline Variabel & Nilai ADF t & \multicolumn{3}{|l|}{ Nilai Kritis MacCinnon } & Keterangan \\
\cline { 3 - 5 } & stastistic & 1 persen & 5 persen & 10 persen & \\
\hline $\begin{array}{l}\text { GDP } \\
\text { percapita }\end{array}$ & 2.743196 & -3.679322 & -2.967767 & -2.622989 & $\begin{array}{l}\text { Tidak } \\
\text { Stasioner }\end{array}$ \\
\hline Jalan & 1.277955 & -3.689194 & -2.971853 & -2.625121 & $\begin{array}{l}\text { Tidak } \\
\text { Stationer }\end{array}$ \\
\hline Listrik & 1.871147 & -3.752946 & 2.998064 & -2.638752 & $\begin{array}{l}\text { Tidak } \\
\text { Stationer }\end{array}$ \\
\hline Telepon & 2.660034 & -3.752946 & -2.998064 & 2.638752 & $\begin{array}{l}\text { Tidak } \\
\text { Stsioner }\end{array}$ \\
\hline
\end{tabular}

Tabel 1 memperlihatkan bahwa terdapat empat variabel yang tidak stasioner pada level, yakni GDP Percapita, Jalan, lsitrik dan Telepon . Berdasarkan hal tersebut, maka kembali dilakukan pengujian Augmented Dickey Fuller Test lanjutan pada tingkat first difference.

Tabel 2. Hasil Uji Augmented Dickey Fuller pada First Difference

\begin{tabular}{|l|l|l|l|l|l|}
\hline Variabel & Nilai ADF t & \multicolumn{3}{|l|}{ Nilai Kritis MacCinnon } & Keterangan \\
\cline { 3 - 5 } & stastistic & 1 persen & 5 persen & 10 persen & \\
\hline $\begin{array}{l}\text { GDP } \\
\text { percapita }\end{array}$ & -6.814129 & -3.689194 & -2.971853 & -2.625121 & Stasioner \\
\hline Jalan & -9.157320 & -3.689194 & -2.971853 & 2.625121 & Stasioner \\
\hline Listrik & -3.269750 & -4.416345 & -4.416345 & -3.248592 & Stasioner \\
\hline Telepon & -3.904237 & -4.440739 & -3.632896 & -3.254671 & Stasioner \\
\hline
\end{tabular}

Tabel 2 menunjukkan bahwa semua data yang digunakan dalam penelitian ini stasioner pada first difference.

\section{Engle-Granger Cointegration}


Uji kointegrasi Engle-Granger digunakan untuk mengestimasi hubungan jangka panjang antara GDP per capita dengan jalan, listrik dan telepon. Tahap awal dari uji kointegrasi Engle-granger adalah dengan meregresi persamaan OLS antara variabel dependen dan variabel independen. Kemudian setelah meregresi persamaan didapatkan residual dari persamaan tersebut. Uji ADF pada residual bersifat stasioner pada level atau $\mathrm{I}(0)$ sehingga dapat dikatakan bahwa variabel yang digunakan cenderung menuju keseimbangan pada jangka panjang walaupun pada tingkat level terdapat variabel yang tidak stasioner.

Tabel 3. Uji Augmented Dickey Fuller Persamaan Residual

\begin{tabular}{|l|l|l|l|l|l|}
\hline Variabel & Nilai ADF $\mathrm{t}$ & \multicolumn{2}{|l|}{ Nilai Kritis MacCinnon } & Keterangan \\
\cline { 3 - 5 } & stastistic & 1 persen & 5 persen & 10 persen & \\
\hline ECT & -4.602184 & -3.689194 & -2.971853 & -2.625121 & Stasioner \\
& & & & & \\
\hline
\end{tabular}

Berdasarkan informasi yang tertuang dalamTabel 3, diketahui bahwa nilai ADF $t$-statistic lebih kecil daripada nilai kritis MacKinnon pada taraf nyata 1 persen, 5 persen, maupun 10 persen, sehingga residual persamaan regresi stasioner pada tingkat level. Berdasarkan hasil Engle-Granger Cointegration terbentuklah persamaan berikut ini :

$$
\begin{gathered}
\text { GDP_CAP_TAN }=9.868366929 \mathrm{e}+010 * \text { JALAN }+786328852.1 * \text { LISTRIK }- \\
1826072067 * \text { TELEPON }
\end{gathered}
$$

\section{Error Correction Model (ECM)}

Error Correction Model (ECM) digunakan untuk mengestimasi model dinamis jangka pendek dari variabel Produk Domestik Bruto Perkapitaperkapita. Penggunaan metode estimasi ECM dapat menggabungkan efek jangka pendek dan jangka panjang yang disebabkan oleh fluktuasi dan time lag dari masing variabel independen (Thomas, 1997). Dalam penelitian ini, estimasi ECM untuk Produk Domestik Bruto Perkapita dilakukan dengan cara merestriksi variabel-variabel yang berpengaruh terhadap Produk Domestik Bruto Perkapita . Berdasarkan hasil Error Correction Model (ECM) terbentuklah persamaan berikut ini :

$$
\begin{gathered}
\mathrm{D}\left(\mathrm{GDP} \_\mathrm{CAP} \_\mathrm{TAN}\right)=2.8060 * \mathrm{D}(\mathrm{JALAN})+500731872.1 * \mathrm{D}(\mathrm{LISTRIK})- \\
1830655551 * \mathrm{D}(\mathrm{TELEPON})+7.098187674 \mathrm{e}+010 * \mathrm{JALAN}(-1)+
\end{gathered}
$$


Uji autokorelasi yang digunakan dalam penelitian ini adalah BreuschGodfrey Serial Correlation LM Test . Nilai probabilitas $(0,3238)$ yang lebih besar apabila dibandingkan dengan taraf nyata 10 persen menunjukkan bahwa tidak terdapat permasalahan autokorelasi dalam model persamaan tersebut. Uji heteroskedastisitas yang digunakan dalam penelitian ini adalah White Heteroscedasticity Test (no cross term). Probabilitas Obs*R-squared sebesar 0,64244 yang lebih besar dibandingkan taraf nyata 10 persen membuat model persamaan dinamis jangka pendek ECM terbebas dari problem heteroskedastisitas.

Tabel 4.Hasil Estimasi Faktor-faktor yang mempengaruhi Produk Domestik Bruto Perkapitapada Jangka Panjang

\begin{tabular}{|l|l|l|}
\hline Variabel & Koefisien & Probabilitas \\
\hline Jalan & 3.659780 & 0,0011 \\
\hline Listrik & 4.052408 & 0,0004 \\
\hline Telepon & 4.052408 & 0,0000 \\
\hline
\end{tabular}

Menurut tabel 4 menujukan bahwa secara jangka panjang infrastruktur jalan, listrik dan telepon memiliki pengaruh yang signifikan dan postif. Hal ini ditunjukan pada probabilitas masing masing koefisiien dibawah taraf kepercayaan $5 \%$.

Tabel 5. Hasil Estimasi Faktor-faktor yang Mempengaruhi Produk Domestik Bruto Perkapita pada Jangka Pendek

\begin{tabular}{|l|l|l|}
\hline Variabel & Koefisien & Probabilitas \\
\hline Jalan & & \\
& $1.80 \mathrm{E}+11$ & 0.1594 \\
\hline Listrik & $-5.87 \mathrm{E}+08$ & 0.0615 \\
\hline Telepon & $1.28 \mathrm{E}+09$ & 0,2610 \\
\hline
\end{tabular}

Menurut tabel 5 menujukan bahwa secara jangka pendek infrastruktur jalan, listrik dan telepon tidak memiliki pengaruh yang signifikan. Hal ini ditunjukan pada probabilitas masing masing koefisiien diatas taraf kepercayaan $5 \%$. 


\section{Pengaruh Jalan terhadap Produk Domestik Bruto Perkapita Perkapita}

Sumber daya di daerah sulit berkembang disebabkan oleh infrastruktur yang kurang. Sebagai contoh, gambar 8 yang berbentuk Sactter graph mengambarkan hubungan panjang per luas wilayah dengan pendapatan per kapita propinsi propinsi di Indonesia.

Gambar 3 : Keterkaitan antara Panjang Jalan per luas wilayah dengan GNP Per Kapita per Provinsi-provinsi.Tahun 1995

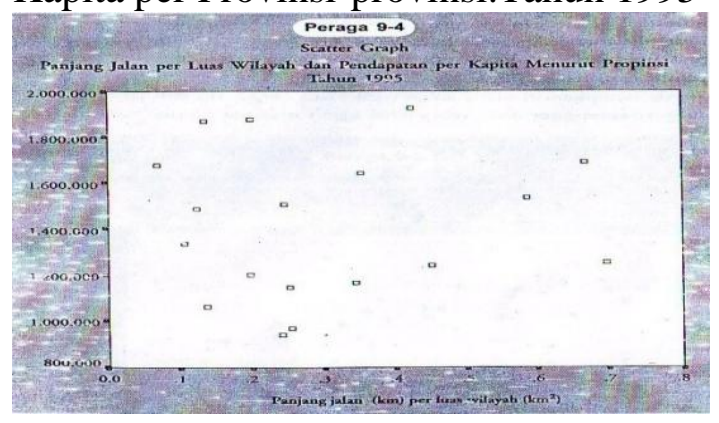

Sumber : Basri (2002:306)

Selain kesimpulan diatas korelasi positif berarti juga memberi makna bahwa semakin tinggi pendapatan perkapita susatu daerah maka akan semakin tinggi pula kemampuan untuk menyediakan infrastruktur jalan karena kemampuan membayar pajak yang lebih tinggi dan daya beli masyarakat meningkat (Basri,2002:303-304)

\section{Pengaruh Listrik terhadap Produk Domestik Bruto Perkapita Perkapita}

Pemakaian energi komersial pada tahun 1970 berjumlah sebesar 9,851 juta TBE (tone batu bara ekuivalen) dan pada tahun 1979 sebanyak 33,1 juta TBE, atau peningkatan rata rata $14,4 \%$ setahun. Konsumsi energi listrik pada tahun 1970 sejumlah 2,918.10 kwh dan pada tahun 1979 naik dengan rata rata 10,523.10 kwh, bermakna suatu kenaikan rata rata setahun dengan 15,4 \%. Energi listrik ini berasal dari PLN maupun bukan PLN dan pembangkitan sendiri oleh industri. Angka angka tersebut diatas tercantum pada tabel 6.

Tabel 6. Jumlah Penduduk, Energi, Listrik, dan Elastisitas di Indonesia , 1970 dan 1979

\begin{tabular}{|l|l|l|l|l|l|}
\hline NO & Penjelasan & Satuan & Tahun 1970 & $\begin{array}{l}\text { Tahun } \\
1979\end{array}$ & Naik \% tahun \\
\hline 1 & Jumlah penduduk & Juta & 117,3 & 143,7 & 2,57 \\
\hline 2 & $\begin{array}{l}\text { Produk Domestik } \\
\text { Bruto }\end{array}$ & $10^{12}$ Rupiah & 5,182 & 9,990 & 7,5 \\
\hline
\end{tabular}




\begin{tabular}{|l|l|l|l|l|l|}
\hline 3 & PDB per Kapita & $\begin{array}{l}10^{12} \\
\text { Rupiah/Kapita }\end{array}$ & 44,2 & 67,7 & 4,8 \\
\hline 5 & Konsumsi listrik & $10^{9} \mathrm{kwh}$ & 2,918 & 10,523 & 15,4 \\
\hline 6 & Listrik per kapita & Kwh/K.T. & 24,9 & 73,2 & 12,7 \\
\hline 7 & Listrik: Energi & $\%$ & 9,87 & 10,59 & 0,8 \\
\hline 8 & Listrik/K : PDB/K & Kwh/10 $0^{3}$ Rupiah & 0,563 & 1,08 & 7,5 \\
\hline
\end{tabular}

Elastisitas Energi $=14,4: 7,5=1,92$

Elastisitas Listrik $=15,4: 7,5=2,05$

Sumber: Kadir (1995:563)

Menurut Kadir (1995:564) pengaruh tenaga listrik terhadap produksi industri dapat dipelajari sebagai berikut: (a) Pengaruh dalam arti adanya tenaga listrik sehingga mendorong terbentuknya atau berkembangnya kegiatan industri. Hal ini memang telah menjadi perdebatan akademis. Manakah yang harus lebih dulu datang, listrik atau industri. Persoalan klasik ayam dan telur teranalogikan dengan hal ini. (b) Pengaruh harga tenaga listrik dalam struktur biaya produksi industri. Berapa besarkah komponen tenaga listrik sebagai unsur bagian biaya industri? Pengaruh ini akan coba diuraikan.

Penentuan bagian daripada biaya listrik dalam produksi secara keseluruhan suatu kegiatan industri dapat dilakukan dengan mempelajari tiga unsur yang terdiri atas (a) Biaya langsung energi listrik dalam pembuatan produk tersebut; (b) Biaya energi listrik yang terkandung dalam produksi dan penyediaan bahan bakar dan bahan bahan lain yang diperlukan untuk pembuatan produk akhir yang dipelajari; (c) Bagian biaya energi listrik yang termasuk didepresiasi aktiva tetap pabrik itu, seperti bangunan, mesin dan asset tetap lainya.

Suatu studi yang mempelajari biaya langsung harga energi listrik di suatu pabrik bir, pabrik rokok, pabrik sepatu dan pabrik ban memberikan hasil-hasilnya sebagai mana terlihat pada tabel 7.

Tabel 7. Pengaruh Energi Listrik Langsung Terhadap Produksi Beberapa Jenis Industri

\begin{tabular}{|l|l|l|l|l|l|}
\hline NO & Keterangan & \multicolumn{4}{|c|}{ PABRIK } \\
\cline { 3 - 6 } & & Bir & Rokok & Sepatu & Ban \\
\hline 1 & $\begin{array}{l}\text { Pemakai } \\
\text { listrik }\end{array}$ & $3.057 .684 \mathrm{kwh}$ & $364.522 \mathrm{kwh}$ & $843.170 \mathrm{kwh}$ & $\begin{array}{l}1.614 .120 \\
\text { kwh }\end{array}$ \\
\hline 2 & Produksi & 5.130 .100 liter & $\begin{array}{l}73.718 .650 \\
\text { bungkus }\end{array}$ & $\begin{array}{l}1.038 .258 \\
\text { pasang }\end{array}$ & $\begin{array}{l}393.093 \\
\text { buah }\end{array}$ \\
\hline 3 & Biaya & $6,4 \%$ & $0,41 \%$ & $2,45 \%$ & $4,7 \%$ \\
\hline
\end{tabular}




\begin{tabular}{|l|l|l|l|l|l|}
\hline & Langsung & & & & \\
\hline 4 & Listrik & 0,596 & 0,05 & 0,8 & 4,11 \\
\hline 5 & $\begin{array}{l}\text { Listrik per } \\
\text { Unit produksi }\end{array}$ & $0,569 \mathrm{kwh} / \mathrm{liter}$ & $\begin{array}{l}0,05 \\
\text { kwh/bungkus }\end{array}$ & $\begin{array}{l}0,8 \\
\mathrm{kwh} / \text { pasang }\end{array}$ & $\begin{array}{l}4,11 \\
\mathrm{kwh} / \mathrm{ban}\end{array}$ \\
\hline
\end{tabular}

Sumber: Kadir dalam Kadir (1995:565)

Suatu studi lain yang mempelajari hal yang sama pada beberapa jenis industri lain seperti beras, gula, pemintalan tekstil dan semen memberikan angka angka sebagaimana tampak dalam tabel dibawah ini.

Data yang terdapat pada tabel 7 merupakan angka-angka dari industri di Indonesia. Angka angka mengenai pemakaian energi per satuan produksi di luar negeri menurut Lincoln tercantum dalam tabel 8 berikut, yang menyangkut produk produk seperti gula dan rokok.

Tabel 8. Pengaruh Langsung Energi Listrik terhadap Beberapa Produk Industri

\begin{tabular}{|l|l|l|l|}
\hline NO & Keterangan & $\begin{array}{l}\text { Listrik per } \\
\text { Satuan }\end{array}$ & $\begin{array}{l}\% \text { Biaya } \\
\text { Listrik }\end{array}$ \\
\hline 1 & Beras & $20 \mathrm{kwh} /$ ton & 0,39 \\
\hline 2 & Gula & $200 \mathrm{kwh} / \mathrm{ton}$ & 3,44 \\
\hline 3 & Pemintalan & $4860 \mathrm{kwh} / \mathrm{ton}$ & 11,43 \\
\hline 4 & Tekstil & $1,36 \mathrm{kwh} / \mathrm{m}$ & 7,30 \\
\hline
\end{tabular}

Sumber: Widhoyoko dalam Kadir (1995:566)

\section{Pengaruh Telepon terhadap Produk Domestik Bruto Perkapita}

Pembahasan mengenai hubungan antara infratsruktur telepon dengan pertumbuhan ekonomi dan Produk Domestik Bruto Perkapitatelah dianalisis oleh Supriadi (1995:25-30). Penelitian tersebut menunjukan bahwa beberapa negara bahwa sektor telekomunikasi secara signifikan terhadap sektor industri dan manufaktur karena sektor sektor tersebut lebih memerlukan telekomunikasi daripada sektor pertanian yang ketergantungannya pada telekomunikasi lebih rendah. Temuan kedua adalah sumbangan setiap percakapan telepon terhadap GNP merentang antara US\$ 3,93-11,80 untuk negara yang GNP/P nya US\$ 20.000. Meskipun besarannya berbeda, Besar kecilnya sumbangan itu tergantung kepada tinggi-rendahnya GNP/P dan disektor mana serta dilokasi dengan karakteristik bagaimana telepon tersebut dibangun. 
Temuan Ketiga, setelah memperhitungkan biaya pembangunan dan pemeliharaan, ratio keuntungan dan biaya (benefit and cost ratio) dari setiap SST berkisar antara 47:1 sampa 2:1. Makin rendah GNP/P, makin tinggi ratio keuntungan dan biaya (K/B) itu, dan makin tinggi GNP/P, makin rendah ratio itu. Artinya investasi US\$ 1000 untuk satu SST di negara yang GNP/P yang hanya US\$ 100, akan memberikan kentungan sebesar US\$ 47.000 sedangkan jika investasi dilakukan di negara yang GNP/P US\$20.000, keuntungan itu hanya dua kali lipat menjadi US\$ 2.000

Dengan asumsi yang kasar (tanpa memperhitungkan faktor inflasi dll) kita dapat memperkirakan berapa sumbangan telekomunikasi terhadap GNP. Misalnya pada tahun 1979, GNP/P kita US\$ 430, jumlah penduduk 145,7 juta dan jumlah SST 598.662. Jika setiap SST memberikan kontribusi US\$ 2.876 maka sumbangan sektor telekomunikasi terhadap GNP adalah US\$ 1,72 Miliar, atau sekitar 2,72\% terhadap GNP. Pada tahun 1983, dengan 666.133 SST, penduduk 157,3 juta, dan GNP/P US\$ 560, sedangkan kontribusi setiap SST sebesar US\$ 2.065, maka dipereoleh sumbangan $1,57 \%$ terhadap GNP.

Pada tahun 1983, menurut Bank Dunia, Indonesia hanya menginvestasikan 0,10\% dari GNP untuk telekomunikasi, berarti ada keuntungan 15 kali lipat. Dengan menggunakan acuan itu juga kita bisa memperkirakan sumbangan tahun 1991 dengan GNP/P US\$ 580, 1.564541 SST, dan penduduk 180 juta, adalah sekitar US\$ 3,23 Miliar (Rp. 6,46 triliun) atau 3,10\% dari GNP. Padahal, pada tahun itu jumlah total investasi untuk subsektor telekomunikasi hanya $0,40 \%$ dari GNP, berarti rasio K/B sekitar 8 : 1. Pada tahun 1998. Dengan asumsi penduduk Indonesia mencapai 200 juta, jumlah SST 7 juta, GNP/P sekitar US\$ 800 dan setiap SST memberikan sumbangan US\$ 1674, maka sumbangan telekomunikasi mencapai sekitar US\$ 11,72 miliar atau sekitar 7,34\% terhadap GNP.

Bahwa infrastruktur jalan, lsitrik dan telepon tidak secara berpengaruh terhadap Produk Domestik Bruto Perkapitasecara jangka perkapita karena sifat infratsruktur yang mendukung perekonomian secara tidak langsung. Hal ini sesuai dengan karakteristik infrastruktur yangg bersifat sebagai faktor penunjang atau faktor pendukung dalam kegiatan ekonomi 


\section{KESIMPULAN}

Berdasarkan hasil penelitian yang dilakukan, kesimpulan yang dapat diambil untuk menjawab permasalahan yang diteliti, yaitu: (1) Ketersediaan infrastruktur publik (jalan, listrik dan telepon) yang dikaji dalam penelitian ini semuanya mempengaruhi Produk Domestik Bruto Perkapitaperkapita di Indonesia untuk jangka panjang; (2) Ketersediaan infrastruktur publik (jalan, listrik dan telepon) yang dikaji dalam penelitian ini semuanya tidak mempengaruhi Produk Domestik Bruto Perkapitaperkapita di Indonesia untuk jangka pendek.

\section{DAFTAR RUJUKAN}

Arsyad, Lincoln. 2004. Ekonomi Pembangunan.(Edisi Keempat). Yogyakarta: BP STIE YKPN

Badan Pusat Statistik.1981. Buku Saku Statistik Indonesia 1980-1981..Jakarta: Badan Pusat Statistik.

Badan Pusat Statistik. 1983. Buku Saku Statistik Indonesia 1983. Jakarta: Badan Pusat Statistik.

Badan Pusat Statistik. 1989. Buku Saku Statistik Indonesia 1989. Jakarta: Badan Pusat Statistik.

Badan Pusat Statistik. 1994. Buku Saku Statistik Indonesia1994. Jakarta: Badan Pusat Statistik.

Badan Pusat Statistik.1998. Buku Saku Statistik Indonesia 1998. Jakarta: Badan Pusat Statistik.

Badan Pusat Statistik. 2002. Buku Saku Statistik Indonesia 2002. Jakarta: Badan Pusat Statistik

Badan Pusat Statistik. 2002. Buku Saku Statistik Indonesia 2002. Jakarta: Badan Pusat Statistik

Badan Pusat Statistik 2007. Statistik Indonesia 2007. Jakarta: Badan Pusat Statistik

Baldwin, John R. and Dixon, Jay, Infrastructure Capital: What is it? Where is it? How Much of it is There? (March 12, 2008). Canadian Productivity Review Research Paper No. 16.http://ssrn.com/abstract=1507883 diakses pada 22 November 2009

Basri,Faisal. 2002. Perekonomian Indonesia:Tantangan dan Harapan Bagi Kebangkitan Ekonomi Indonesia. Jakarta: Erlangga.

Case,Karl E,Fair,C Ray. 2004. Prinsip prinsip Ekonomi Makro (Bambang Sarwiji). Jakarta: Indeks Kel Gramedia.

Égert, Balázs, Kozluk, Tomasz J. and Sutherland, Douglas. Infrastructure and Growth: Empirical Evidence (July 14, 2009). CESifo Working Paper 
Series No. 2700; William Davidson Institute Working Paper No. 957; OECD Economics Department Working Paper No. 685.

http://ssrn.com/abstract=1360784 diakses pada 22 November 2009

Garmendia Briceno, Cecilia, Estache, Antonio and Shafik, Nemat, Infrastructure Services in Developing Countries: Access, Quality, Costs, and Policy Reform (December 2004). World Bank Policy Research Paper No. 3468. http://ssrn.com/abstract $=643265$ diakses pada 22 November 2009

Kadir,Abdul. 1995. Energi:Sumber Daya,Inovasi,Tenaga Listrik dan Potensi Ekonomi (Edisi Kedua/Revisi).Jakarta: UI Press.

Kuncoro,Mudrajad. 2006. Ekonomi Pembangunan : Teori, Masalah dan Kebijakan. Yogyakarta: UPP STIM YKPN.

Mankiw,N Gregory. 1997. Pengantar Ekonomi (Jilid II). Alih bahasa oleh Imam Nurmawan. Jakarta: Erlangga.

Mankiw, N Gregory. 2003. Teori Makroekonomi (Edisi Kelima). Alih bahasa oleh Imam Nurmawan. Jakarta: Erlangga.

Permana,Chandra Darma. 2009. Analisis Peranan dan Dampak Investasi Infratsruktur terhadap Perekonomian Indonesia.Bogor: Fakultas Ekonomi dan Manajemen Institut Pertanian Bogor (IPB). http://iirc.ipb.ac.id/jspui/bitstream/123456789/11590/2/H09cdp.pdf diakses pada 27 Juni 2010

Rahardja,Prahatma,Manurung,Mandala. 2005. Teori Ekonomi Makro (Suatu Pengantar)(Edisi Ketiga). Jakarta" Lembaga Penerbit FE UI.

Seethepalli, Kalpana, Bramati, Maria Caterina and Veredas, David, How Relevant is Infrastructure to Growth in East Asia? (April 1, 2008). World Bank Policy Research Working Paper Series, Vol. , pp. -, 2008. http://ssrn.com/abstract=1149100 diakses pada 22 November 2009

Sukirno,Sudono. 2007. Ekonomi Pembangunan: Proses,Masalah,dan Dasar Kebijakan. Jakarta: Kencana Persada Media Group.

Supriadi,Dedi. 1996. Era Baru Bisnis Telekomunikasi. Bandung: STT Telkom.

Thomas, R.L. 1997. Modern Econometrics : an Introduction. Addison-Wesley: Essex.

Todaro,P Micahel, Smith C Stephen. 2007. Pembangunan Ekonomi di Negara Dunia Ketiga (Edisi kedembilan)Jilid1.(Haris Munanda,Puji A.L). Jakarta: Erlangga.

Um Paul Noumba, Straub, Stéphane and Vellutini, Charles, Infrastructure and Economic Growth in the Middle East and North Africa (October 1, 2009). World Bank Policy Research Working Paper Series, Vol. , pp. -, 2009. diakses pada 22 November 2009

Wahyuni, Krismanti Tri.2009. Analisis Pengaruh Infrastruktur Ekonomi dan Sosial Terhadap Produktivitas Ekonomi di Indonesia. Bogor:Fakultas Ekonomi dan Manajemen.Institut Pertanian Bogor 
(IPB).http://iirc.ipb.ac.id/jspui/bitstream/123456789/13210/2/H09ktw.pdf diakses pada 27 Juni 2010

World Bank(2010). Telephone lines. (per 100 people).http://data.worldbank.org/indicator IT.MLT.MAIN.P2 diakses pada 26 Mei 2010

World Bank (2007). Kajian Pengeluaran Publik Indonesia Bab 5 Infrastruktur. http://siteresources.worldbank.org/INTINDONESIA/Resources/22627111 68333550999/PERFBAB5-Infrastruktur.pdf diakses pada 22 November 2009

World Bank(2010). Electric power consumption( $k$ Wh per capita). http://data.worldbank.org/indicator EG.USE.ELEC.KH.PC diakses pada 26 mei 2010

World Bank (2010).GDP (constant 2000 US\$).

http://data.worldbank.org/indicator NY.GDP.MKTP.KD diakses pada 26 $\underline{\text { Mei } 2010}$

World Bank (2010).Mobile and fixed-line telephone subscribers(per 100 people). http://data.worldbank.org/indicator \$). IT.TEL.TOTL.P2 diakses pada 26 Mei 2010

diakses pada 26 Mei 2010 